Babayiğit, Ö. ve Gökçe, A. (2018). Okuma-yazma bilmeyen yetişkinlerin okuma-yazma öğrenme nedenlerinin incelenmesi. Ana Dili Ĕgitimi Dergisi, 6(3), 813-826.

$\begin{gathered}\text { Ana Dili Eğitimi Dergisi } \\ \text { Journal of Mother Tongue Education } \\ \text { www.anadiliegitimi.com }\end{gathered}$
Geliş/Received: 08.06 .2018 Kabul/Accepted:13.07.2018

\title{
Okuma-Yazma Bilmeyen Yetişkinlerin Okuma-Yazma Öğrenme Nedenlerinin İncelenmesi
}

\author{
Özgür BABAYIĞiT*
}

Ayhan GÖKÇE $E^{* *}$

\begin{abstract}
Öz
Bu araştırmanın amacı, okuma-yazma kurslarına devam eden yetişkinlerin bu kurslara başlama nedenlerinin tespit edilmesidir. Araştırma, ülkemizdeki yetişkinlerin neden okuma-yazma öğrenemediklerini ortaya koyması, okuma-yazma bilmemenin sonuçlarını belirtmesi, yetişkinlerin okuma-yazmayı öğrenmeyi istemelerinin nedenlerini açıklaması açısından önemlidir. Araştırma, nitel araştırma yöntemlerinden olgu bilim türündedir. Katılımcıların belirlemesinde amaçlı örnekleme yöntemlerinden kolay ulaşılabilir durum örneklemesi kullanılmıştır. Kolay ulaşılabilir durum örneklemesi kapsamında Yozgat ilinde okuma-yazma kursuna devam eden yirmi bir yetişkin katılımcıya ulaşıımışır. Veri toplama aracı olarak araştırmacılar tarafından geliştirilen yarı yapılandırılmış görüşme formu kullanılmışır. Araştırma, 2018 yılı mart ayında gerçekleştirilmiştir. Araştırma kapsamında, okuma-yazma kursuna katılmıs yirmi bir yetişkin birey ile görüşme yapılmıştır. Yapılan görüşmeler, izin alındıktan sonra ses kayıt cihazına kaydedilmiştir. Görüşmeler okuma-yazma kursunda, teneffüslerde gerçekleştirilmiştir. Toplamda 256 dakikalık görüşme yapılmıştır. Verilerin analizinde tümevarımsal olarak gerçekleştirilen içerik analizi kullanılmıştır. Veriler öncelikle kodlanmışıı. Ardından kodlardan kategorilere ulaşıımışır. Ulaşıın kategorilerden ise temalara ulaşılmıştır. Veriler belirli temalar altında toplanarak, okuyucunun kolayca anlayabileceği bir şekilde sunulmuştur. Yetişkinlerin okuma yazma öğrenme nedenlerinin incelendiği bu araştırmada, verilerin içerik analizi sonucunda, dört adet temaya ulaşılmıştır. Araştırma sonucunda ulaşılan temalar şunlardır: gündelik işler için, kuran, kitap, gazete okumak için, hastane işleri için, dolandırılmamak için. Araştırma sonuçları kapsamında önerilerde bulunulmuştur.
\end{abstract}

Anahtar Kelimeler: Yetişkin, okuma, yazma, öğrenme

Investigation of Illiterate Adults' Reasons for Learning Literacy

\begin{abstract}
The aim of this study was to determine the participating adults' reasons for attending literacy courses. Research is important in order to explain why some adults in Turkey have failed to learn to read and write, to express the consequences of illiteracy, and to explain the reasons for adults to learn to read and write. The research was designed as a phenomenology study which is a qualitative research method. An easily accessible case sample was used in the purposeful sampling of the participants. Within the context of easy-access case sampling, twenty-one adult participants attending the literacy course in the Yozgat province were reached. A semi-structured interview form developed by the researchers was used as the data collection tool. The research was conducted in March 2018. Within the scope of the study, twenty-one adults who
\end{abstract}

\footnotetext{
* Dr. Öğr. Üyesi, Yozgat Bozok Üniversitesi, Eğitim Fakültesi, Temel Eğitim Bölümü, Yozgat, E-posta: ozgur.babayigit@bozok.edu.tr

** Sınıf Öğretmeni, Şehit Önder Muratoğlu İlkokulu, Yozgat, E-posta: ayhangokce66@gmail.com
} 
participated in the literacy course were interviewed. In the analysis of the data, inductive analysis was used for thematic analysis. The data were primarily coded. This led to the emergence of themes. Four themes emerged in the thematic analysis of the data. The themes that emerged showed the reasons for adults to learn to write and write. Those reasons were: doing daily tasks, being able to read the Quran and other printed materials, seeking medical help in hospitals, and avoiding defraudation. Suggestions were made based on the findings.

Keywords: Adult, Reading, Writing, Learning

\section{Giriş}

Yetişkin eğitimi diğer dünya ülkelerinde olduğu gibi, ülkemizde de üzerinde titizlikle durulan bir konudur. Milli Eğitim Bakanlığı Halk Eğitim Müdürlüğü, belediyeler, ceza infaz kurumları bünyesinde yetişkinlere yönelik çeşitli kurslar düzenlenmektedir. Düzenlenen bu kurslardan birisi de yetişkinler için okuma-yazma kurslarıdır. Yetişkinler için düzenlenen okuma-yazma kurslarıyla, kısa zamanda, hızlandırılmış bir şekilde okuma-yazma öğretilmektedir. Çeşitli nedenlerle ilkokula gidememiş veya okuma-yazma öğrenememiş yetişkinlere okuma-yazma ücretsiz olarak öğretilmektedir. Araştırmanın giriş bölümünde ilk olarak yetişkinler için okuma-yazma öğrenmenin önemi üzerinde durulmuştur. Daha sonra ülkemizde 2018 yılında gerçekleştirilen okuma-yazma seferberliğine değinilmiştir. Son olarak yetişkinler için okuma-yazma öğretim programı üzerinde durulmuştur.

Ülkemizde geçmiş yıllardan günümüze zorunlu eğitim çağı dışında olan okuma-yazma öğrenememiş ve temel eğitimden mahrum kalmış yetişkinler için program çalışmaları yapılmıştır. Bunlar yetişkinlerin okuma-yazma ve temel eğitim eksikliğini gidermek için 1980'e kadar “Okuma Yazma Programları", "Okuma Yazmayı, Temel Becerileri Geliştirme Programları" ve "ilkokulu Bitirme Programları"dır. 1980'den sonraysa bu programlar "I ve II. Kademe" olarak iki aşamalı şekilde uygulanmaya başlanmıştır. "Yetişkinler İçin I. Kademe Okuma Yazma Öğretimi ve Temel Eğitim Programı" yetişkinlerin, okuma-yazma ve temel matematik becerileri kazanmalarını; bu becerilerini öğrenme, şahsi ve toplumsal gelişimleri için kullanabilmelerini; çevresiyle uyumlu, kendisiyle barışık, yerel, ulusal, evrensel insani değerlere ve öz güvene sahip olmalarını temel felsefe olarak kabul etmektedir (MEB, 2018, s. 3).

İnsanların temel becerilerinden olan okuma-yazmanın öğretimi hem Türkiye'de hem de dünyada gündemde olan konulardan bir tanesidir. Eğitim standartları sürekli yükselmesine rağmen toplumlarda okuryazarların toplam nüfusa oranı beklenen iyileşmeyi gösterememiş, önemli sayıda yetişkin en temel becerilerden biri olan okuryazarlık becerisini edinemeden örgün eğitimin dışında kalmıştır. Bu nedenle okuryazarlığın yaygınlaştırılması hem gelişmiş hem de gelişmekte olan ülkelerde sürmekte olan bir çabadır. Türkiye'de de okuma-yazma seferberlikleri ve bölgesel faaliyetlerde okuma yazma bilmeyen bireyleri okuryazar hale getirmeye yönelik çabalar devam etmekte ve çeşitli programlar uygulanmaktadır (Durgunoğlu, Öney, Kuşçul ve Cantürk, 1997, s. 4). Okuryazarlık eğitimi 
sadece bir becerinin kazanımı olmakla kalmaz, bireyin dünyaya bakışını yeniden biçimlendirir. Bu biçimlendirme yazı sistemlerinin oluşturduğu bakış açısının hayatın pek çok alanında yaygınlaşmaya başlamasıyla kendini gösterir. Genel görüş, kişinin sadece okuma yazma becerilerini edindiği yönünde ise de uzmanların okuryazarlığa bakışı bundan daha da karmaşıktır. Kişiler, okuryazar ya da değil diye nitelendirilmektense okuryazarlığın farklı seviyelerinde görülürler. İşlevsel okuryazarlıksa okuryazarlığın varsayıldığı toplumlarda okuryazarlığı varsayan işlevleri yerine getirmeyi anlatan bir kavramdır. Okuryazarlığın varsayıldığı toplumlarda günlük yaşamı sürdürebilmek için gerekli olan pek çok işlemi yapmakta okuryazar olmak birincil koşuldur. Bu gibi toplumlarda okuryazar olmayan bireyler bir becerinin eksikliğini duymanın yanında toplumda yer almakta ve gündelik yaşamdaki işlevleri yerine getirebilmekte de problemlerle karşılaşmaktadırlar (Gülgöz, 2003, s. 3).

Okumaz-yazmazlık problemi içerisinde önemli yere sahip başka bir konu da okuma-yazmanın unutulmasıdır. Bu duruma Fransızca da "Alettrisme" adı verilmektedir. Alettrisme her ne kadar yeni bir kelimeyse de bununla anlatılmak istenen eskiden beri var olan bir olgudur. 1980 senesi başında sanayileşmiş ülkelerde fark edilen ve gittikçe sayıları artan "alettres"ler (okuma-yazmayı unutanlar) okuma-yazmayı öğrenmiş, ancak hiç okuyup yazmadıkları için zamanla bu becerilerini kaybetmiş kişilerdir (Güneş, 1991, s. 21). Kişisel kazançların yanında okuma-yazma, toplumsal işgücünün akılcı kullanımı, toplumsal kaynakların dağılımı ve vatandaşların siyasal ve ekonomik hayata katılımını sağlamak bakımından da önemli bir yere sahiptir. Ekonomik açıdan iddialı olmayı hedefleyen ülkelerde yetişkin okuryazarlığı programlarının sosyal eşitliği sağlamadaki rolü görmezden gelinemez (Durgunoğlu, Öney, Kuşçul ve Cantürk, 1997, s. 5). Bir tarafta hiç okuma-yazma öğrenme fırsatına sahip olamamışların, öte yanda okuma-yazmayı unutmuş çok sayıda insanın var olduğu bir dünyada, küreselleşmenin okur-yazarlık kavramının anlamını değiştirmesi ve ölçütlerini yükseltmesi ile birlikte; yetişkin eğitiminin okuma-yazma becerisinin gereği ve önemi, okul eğitiminin gelişmesine ve yaygınlaşmasına karşın azalmamakta aksine artmaktadır (Miser, 2002, s. 59). Okuma-yazma, yaşadığımız çağın en ciddi dünya sorunlarından bir tanesidir. Geri kalmışlıkla ve yoksullukla belli ölçüde ilişkilidir. Ulusların varlıklarını sürdürebilmeleri ve kalkınabilmeleri için temel unsurlardan bir tanesidir. Okumaz-yazmazlık bir kader değildir. Sık sık izlenmesi ve köklü çözümlerle önemsenmesi gereken sosyal bir durumdur. Azimle, sabırla, sürekli olarak savaşılmaz ise hemen ortaya çıkmakta ve hızla yayılmaktadır (Güneş, 1997, s. 1).

Milli Eğitim Bakanlığı Hayat Boyu Öğrenme Genel Müdürlüğü'nün 05.02.2018 tarih ve 15923718-10.06.01-E.2350838 sayılı, okuryazarlık seferberliği konulu yazısı, 2018/4 sayılı genelgeyle ülkemizde okuma-yazma seferberliği başlatılmıştır. Anayasa'da yer alan eğitim hakkı ve bilhassa yetişkin okuma yazma eğitimi yaşam boyu öğrenmenin temelini oluşturmaktadır. Eğitim ve öğretim hakkından faydalanamayan ve temel okuma-yazma eğitimini tamamlamayan bireylerin, yasaların 
kendilerine verdiği diğer hak ve özgürlüklerden de yeterince faydalanamadıkları görülmektedir. Bu güne kadar yetişkinlere yönelik okuma yazma faaliyetleri düzenli bir şekilde yürütülmüştür. 2017 TÜik verilerine göre 80 milyon 810 bin olan Türkiye nüfusunun 60 milyonu 14 yaş ve üzerindedir. Bu nüfustan, örgün eğitim çağı dışına çıkmış olanlardan 2.462.613'ü (\% 4,09) hala okuma-yazma bilmemektedir. Bu amaçla Okuryazarlık Seferberliği başlatılması planlanmıştır. Seferberlik kapsamında okuma yazma bilmeyen vatandaşların I. Kademe Için Yetişkin Okuma Yazma Kurslarına katılımları sağlanarak okuryazar hale getirilmesi ve ilkokul seviyesinde öğrenim görmelerini sağlayacak olan II. Kademe İçin Yetişkin Okuma Yazma Kurslarına yönlendirilmesi amaçlanmaktadır.

Yetişkinlerin yaşam boyu kullanabilecekleri dinleme/izleme, konuşma, okuma-yazma ile ilgili dil ve zihinsel beceriler, yetişkinin günlük yaşamında sahip olması beklenen becerilerle temel matematik becerileri edinmelerinin sağlaması, kurs süresinin kısa olması, hususları dikkate alınmıştır. Yetişkinler İçin I. Kademe Okuma Yazma Öğretimi ve Temel Eğitim Programı́nı başarı ile tamamlayan yetişkinlere "Okur Yazarlık Belgesi" verilir. Bu belgeyle isteyen kursiyer Yetişkinler II. Kademe Eğitimi Programı'na devam etme hakkı elde eder. Yetişkinler İçin I. Kademe Okuma Yazma Öğretimi ve Temel Eğitim Programı, Türkçe dersi, yaşam becerisi dersi ve matematik dersi programlarından oluşmaktadır (MEB, 2018, s. 4). Dik temel harflerle ilk okuma yazma öğretimi Tablo 1'deki harf sıralamasına göre yapılmalıdır. Toplam 40 gün olan kurs süresinin ilk 20 gününde tüm sesler verilmelidir (MEB, 2018, s. 12). Harflerin günlere göre dağılımı Tablo 1'de yer almaktadır.

Tablo 1. Harflerin günlere göre dağılımı

\begin{tabular}{|l|c|c|c|c|c|c|c|c|c|c|}
\hline Günler & 1 & 2 & 3 & 4 & 5 & 6 & 7 & 8 & 9 & 10 \\
\hline Harfler & $e$ & l, a & $k$ & $i$ & $n$ & $0, m$ & $u$ & $t$ & $u ̈, y$ & ö, $r$ \\
\hline Günler & 11 & 12 & 13 & 14 & 15 & 16 & 17 & 18 & 19 & 20 \\
\hline Harfler & l, d & s, b & $z$ & $c$ & $g, s$ & $c, p$ & $h$ & $v, g$ & $f$ & $j$ \\
\hline
\end{tabular}

(MEB, 2018, s. 12)

Yetişkinlere yönelik okuma-yazma eğitimiyle ilgili Aziz (1981), Beder (1991), Güneş (1991), Rogers (1992), Mace (1992), Mezirow (1996), Güneş (1997), Quigley (1997), Durgunoğlu, Öney, Kuşçul ve Cantürk (1997), Fingeret ve Drennon (1997), Miser (2002), Gülgöz (2003) tarafından çeşitli 
araştırmalar yapılmıştır. Yapılan araştırmalar incelendiğinde, okumaz-yazmazlıkla olan mücadelenin önemi sıklıkla vurgulanmaktadır. Bunun yanı sıra, okuma-yazma öğrenmenin bireye olan katkıları belirtilmektedir. Yapılan bu araştırmanın amacı, okuma-yazma kurslarına devam eden yetişkinlerin bu kurslara başlama nedenlerinin tespit edilmesidir. Araştırma, ülkemizdeki yetişkinlerin neden okumayazma öğrenemediklerini ortaya koyması, okuma-yazma bilmemenin sonuçlarını belirtmesi, yetişkinlerin okuma-yazmayı öğrenme istemelerinin nedenlerini açıklaması açısından önemlidir. Araştırmanın problemi yetişkinlerin okuma-yazma öğrenme sebepleridir.

\section{Yöntem}

\section{Araştırmanın Modeli}

Araştırma, nitel araştırma yöntemlerinden olgu bilim türündedir. Olgu bilim deseninde farkında olduğumuz ancak derinlemesine ve ayrıntılı bir anlayışa sahip olmadığımız olgulara odaklanılmaktadır. Bize tümüyle yabancı olmayan, aynı zamanda tam anlamını kavrayamadığımız olguları araştırmayı amaçlayan çalışmalar için fenomenoloji uygun bir araştırmadır (Yıldırım ve Şimşek, 2006, s. 72). Olgu bilim insanların fenomenleri nasıl tecrübe ettiklerinin metodolojik, özenli ve derinlemesine bir şekilde resmedilmesi ve betimlenmesidir (Patton, 2014, s. 104; Gliner, Morgan ve Leech, 2015, s. 97; Fraenkel, Wallen ve Hyun, 2011, s. 432). Bir başka tanımla fenomenoloji, bir fenomenin bireylerin ya da belli bir gurubun deneyimleri açısından tanımlanmasıdır (Christensen, Johnson ve Turner, 2015, s. 408).

\section{Araştırma grubu}

Katılımcıların belirlemesinde amaçlı örnekleme yöntemlerinden kolay ulaşılabilir durum örneklemesi kullanılmıştır. Kolay ulaşılabilir durum örnekleme yöntemi araştırmaya hız ve pratiklik kazandırmaktadır (Yıldırım ve Şimşek, 2006, s. 113; Patton, 2014, s. 242). Kolay ulaşılabilir durum örneklemesi kapsamında Yozgat ilinde okuma-yazma kursuna devam eden yirmi bir yetişkin katıımcıya ulaşıımıştır. Katılımcılara ait demografik özellikler Tablo 2'de sunulmaktadır.

Tablo 2. Katılımcıların demografik özellikleri

\begin{tabular}{lcr}
\hline Demografik özellik & $f$ & $\%$ \\
\hline Cinsiyet & & \\
Kadın & 21 & 00 \\
Erkek & 0 & \\
Yaş aralığı & & 5 \\
$30-40$ yaş & 1 & 28 \\
$41-50$ yaş & 6 & 43 \\
$51-60$ yaş & 9 & 19 \\
$61-70$ yaş & 4 & 5 \\
$71-80$ yaş & 1 & 100 \\
\hline Toplam & 21 & \\
\hline
\end{tabular}


Tablo 2'de yer alan katılımcı demografik özellikleri incelendiğinde, okuma-yazma kursuna devam eden yetişkinlerin tamamının kadın olduğu görülmektedir. Okuma-yazma kursuna devam eden katılımcıların yaşları 33 ile 76 arasında değişiklik göstermektedir. Ağılıklı olarak 51-60 yaş aralığındaki katılımcılar oluşturmaktadır.

\section{Veri Toplama Araçları}

Veri toplama aracı olarak araştırmacılar tarafından geliştirilen yarı yapılandırılmış görüşme formu kullanılmıştır. Yarı yapılandırılmış görüşme formunu oluşturmak amacıyla, öncelikle ilgili alan yazın incelenmiştir. Ardından görüşme soruları geliştirilmiştir. Yarı yapılandırılmış görüşme formu, sınıf öğretmenliği alanı Türkçe öğretimi konusunda uzman bir doçent doktor öğretim üyesi ile nitel araştırma yöntemleri konusunda uzman bir doktor öğretim üyesinin uzman görüşüne sunulmuştur. Uzman görüşleri sonrasında yarı yapılandırılmış görüşme formundaki sorular biraz kısaltılmış ve biraz daha basit düzeyde sorulmuştur. Sorular daha basit kelimelerle ve kısa cümlelerle yöneltilmiştir. Yarı yapılandırılmış görüşme formunda şu sorular yer almıştır:

\section{YARI YAPILANDIRILMIŞ GÖRÜŞME FORMU}

Demografik Özellikler

1.Yaş

2.Cinsiyet

Görüşme Soruları

1. Neden okuma-yazmayı çocukken öğrenemediniz? Sebebi nedir? Açıklar mısınız?

2. Okuma-yazma size nerelerde lazım oluyor. Okuma-yazma bilmediğiniz için nerelerde sıkıntılar yaşadınız? Açıklar mısınız?

3. Neden okuma-yazma öğrenmek istiyorsunuz? Okuma-yazma öğrenip neler yapacaksınız?

\section{Verilerin Toplanması}

Araştırma, 2018 yılı mart ayında gerçekleştirilmiştir. Araştırma kapsamında, okuma-yazma kursuna katılmış yirmi bir yetişkin birey ile görüşme yapılmıştır. Yapılan görüşmeler, izin alındıktan sonra ses kayıt cihazına kaydedilmiştir. Görüşmeler okuma-yazma kursunda, teneffüslerde gerçekleştirilmiştir. Toplamda 256 dakikalık görüşme yapılmıştır.

\section{Verilerin Analizi}

Verilerin analizinde tümevarımsal olarak gerçekleştirilen içerik analizi kullanılmıştır. İçerik analizi gözlemler ile başlamakta ve genel örüntüler inşa etmektedir (Patton, 2014: 56). İçerik analizi, verilere dayalı olarak tanımlama, analiz ve temaları sunma aşamalarını içeren bir metottur (Braun ve Clarke, 2006, s. 79). İçerik analizinde temelde yapılan işlem, birbirine benzeyen verileri belirli kavramlar ve temalar çerçevesinde bir araya getirmek ve bunları okuyucunun anlayabileceği bir biçimde düzenleyerek yorumlamaktır (Yıldııım ve Şimşek, 2006, s. 227). Verilerin analizinde, Merriam 
(2013, ss. 165-184)'ın nitel veri analizindeki aşamalar izlenmiştir. Veriler öncelikle kodlanmıştır. Ardından kodlardan kategorilere ulaşılmıştır. Ulaşılan kategorilerden ise temalara ulaşılmıştır. Veriler belirli temalar altında toplanarak, okuyucunun kolayca anlayabileceği bir şekilde sunulmuştur.

Araştırmanın geçerlilik boyutunda uzun süreli etkileşim, uzman incelemesi ile ayrıntılı betimleme yöntemleri kullanılmıştır. Araştırmanın güvenirliğini artırmak amacıyla araştırmacı tarafından planlananlar ve gerçekleştirilenler nitel araştırma yöntemleri konusunda uzman bir öğretim üyesi ile sürecin planlanmasından sonuçlanmasına kadar paylaşılımıştır. Bir araştırmanın geçerlik ve güvenirliği büyük ölçüde araştırmacı etiğine bağlıdır (Merriam, 2013, s. 220). Bu nedenle araştırmada yer alan etik hususların, araştırmanın başından sonuna kadar ifade edilmesi gerekmektedir. Araştırma kapsamında görüşme yapılan bireylerin isimleri gizli tutulmuştur. Gerçek isimlerinin yerine kod adlarla bulgular verilmiştir. Görüşme yapılan bireylere görüşme amacı açıklanmış ve isimlerinin saklı tutulacağı belirtilmiştir.

Verilerin tematik analizi sürecinde, araştırmacılar tarafından ve nitel araştırma yöntemleri konusunda uzman bir öğretim üyesi tarafından kodlamalar yapılmıştır. Görüşme verilerinin analizinin güvenirliği için Miles ve Huberman (2015, s. 64) tarafından geliştirilen güvenirlik formülü [Güvenirlik=Görüş birliği sayısı / (Toplam görüş birliği + Görüş ayrılığı sayısı)] kullanılmıştır. Güvenirlik formülü sonucunda, güvenirlik=.88 bulunmuştur. Bu durum yapılan kodlamaların güvenilir olduğunu göstermektedir. Veriler belirli temalar altında toplanarak, okuyucunun kolayca anlayabileceği bir şekilde sunulmuştur.

\section{Bulgular}

Yapılan içerik analizi sonucunda ulaşılan kodlar, kategoriler ve temalar Tablo 3'te sunulmaktadır.

Tablo 3. Ulaşılan kodlar, kategoriler ve temalar

\begin{tabular}{|c|c|c|}
\hline Ulaşılan Kodlar & Ulaşılan Kategoriler & Ulaşılan Temalar \\
\hline $\begin{array}{l}\text { Çevreden yardım } \\
\text { Utanma } \\
\text { İletişim } \\
\text { Günlük gereksinimler } \\
\text { Teşvik } \\
\text { Kandırılma } \\
\text { Oy kullanma }\end{array}$ & $\begin{array}{l}\text { Çevreye gereksinim } \\
\text { İletişim } \\
\text { Gündelik işler }\end{array}$ & Gündelik işler \\
\hline $\begin{array}{l}\text { Gazete okuma } \\
\text { Kuran okuma } \\
\text { İsim okuma } \\
\text { Kuranı Türkçe okuma }\end{array}$ & $\begin{array}{l}\text { Dini kitap okuma } \\
\text { Gazete okuma }\end{array}$ & $\begin{array}{l}\text { Kuran, kitap, gazete } \\
\text { okumak için }\end{array}$ \\
\hline $\begin{array}{l}\text { Tedavi } \\
\text { Hastane } \\
\text { Sira } \\
\text { Illaç }\end{array}$ & $\begin{array}{l}\text { Eczane } \\
\text { Hastane }\end{array}$ & Hastane işleri için \\
\hline $\begin{array}{l}\text { Kandırma } \\
\text { Dolandırıcı } \\
\text { Polis }\end{array}$ & $\begin{array}{l}\text { Dolandırıcılık } \\
\text { Kandırılma }\end{array}$ & Dolandırılmamak için \\
\hline
\end{tabular}


Tablo 3 incelendiğinde kodlardan kategorilere, kategorilerden ise temalara ulaşıldığı görülmektedir. Okuma-yazma bilmeyen yetişkinlerin okuma yazma öğrenme nedenlerinin incelendiği bu araştırmada, verilerin içerik analizi sonucunda, dört adet temaya ulaşılmıştır. Araştırma sonucunda ulaşılan temaların gündelik işler için, kuran, kitap, gazete okumak için, hastane işleri için, dolandırılmamak için olduğu görülmektedir. Araştırmanın bulguları belirtilen temalara göre açıklanmıştır. Katılımcıların isimleri yerine kodlama kullanılmıştır. Örneğin K2, 43 olarak belirtilen kodlamada K=cinsiyeti (kadın), 2=kodlama numarasını, 43=yaşı belirtmektedir.

1. Tema: Gündelik Işler Için

Okuma-yazma bilmeyen yetişkinlerin okuma-yazma öğrenme nedenlerinin incelendiği bu araştırmada, verilerin içerik analizi sonucunda ulaşılan ilk tema gündelik işler temasıdır. Bu temada, yetişkinlerin okuma-yazma öğrenme nedenlerinden ilkinin ve en önemlisinin gündelik işleri amacıyla olduğu tespit edilmiştir. Tema ile ilgili olarak görüşme yapılan yetişkinler şunları dile getirmişlerdir:

"Çok zorlanıyorum. Küçük çocuklara soruyorum. Bazen zoruma gidiyor. Herkes telefonla oynuyor. Bende telefonla Cuma mesajı atmak istiyorum $(K 1,50)$. Çocuklar okurken sıkıntı yaşadım. Komşulardan yardım aldım. Çocuklara öğretmek için. Kızım okumayı çok istedi $(K 2,43)$. Gündelik yaşam için istedim. Kız çocuğu olduğumuz için bizi okutmadılar. Çok üzüldüm $(K 3,58)$. Günlük hayatımda sıkıntılardan dolayı öğrenmek istiyorum $(K 4,33)$. Okumayı istedim. Kumandaya basmayı bilmiyorum. Evimin adresini bilmiyorum. Çok üzülüyorum. Yüzümüze cahil demiyorlar ama biz yine de üzülüyoruz $(K 5,64)$. Gündelik hayatta çok sıkıntı yaşıyorum. Bankamatikten para çekemiyorum. Telefon edemiyorum. Eşimde çok istedi (K6, 65). Gittiğim yerlerde okuyamıyorum. Eksiklik hissediyorum. Diploma almak istiyorum. Bilemiyorum, okuyamıyorum, utanıyorum. Okumayı çok istiyorum. Sorguna geldiğimizde okuma etkinliğini fark ettim $(K 7,45)$. Bir yere gidince hiçbir şey bilmiyorum. Arabalara binemiyorum. Anneme babama çok kızıorum (K8, 49). Kocam üç senedir yatalak. Kocam beni gönderdi. Bende istiyorum ama unutuyorum (K9, 65). Kaybolmaktan korkuyorum. Yanımda biri olmadan hareket edemiyorum. Köyde yaşadım. Babam gönderemedi. Oğlum çok istedi. Bankamatikten para çekemiyorum $(K 10,58)$. Çok istiyorum. Yolculuk yaparken çok zorluk çekiyorum. Ailem teşvik ediyor. Kendi işimi kendim görmek istiyorum. İçimde uhde kaldı. Küçükken okutmadılar. Erkekler okudu bizi okutmadılar (K12, 55). Evde yalnız yaşıyorum. Tekken etmem gereken işlerde ve günlük hayatta lazım oluyor. Bir yanım yarım gibi oluyor. Arkadaşlarıma akrabalarıma ulaşamıyorum $(K 13,60)$. Annemin ilk çocuğu bendim. Diğer çocuklara bakmam için beni okutmadı. Bu yüzden çok üzgünüm. Geçen gün tartıya çıktı annem gel oku dedi "bende senin gibiyim" dedim. Teknoloji gelişti. Burada yazan isimleri okuyamıyorum (K14, 56). Okumamı ilerletmek istiyorum. Heceleri çatamıyorum. Komşularımla beraber geliyorum (K15, 57). Markette çok sıkıntı çekiyorum. Fiyatları başkalarına soruyorum. Bunun için üzülüyorum. Ablamın okuma yazması var bu 
beni çok üzüyor bundan dolayı babama kızıyorum. Elektrikçi sayacı yazarken bana sordu ben okuyamadım bana kızdı. Eşim çok yardımcı oluyor eşim ilkokul mezunu. Okumayı çok istiyorum. Beş çocuğum var, bir ben bilmiyorum. Gelinlere bir şey sormak ağırıma gidiyor (K16, 44). Annem, babam özelliklede dedem göndermedi. Çok üzüldüm. Kendi çabamla öğrenmeye çalıştım. Kayınvalidem felç olunca bıraktım. Hep öğrenmeyi istedim. Torunuma öğretmek istiyorum (K17, 53). Babam göndermedi okula. Eşime mektup yazacağım, mesaj atmak istiyorum. Bilgisayar kullanmak istiyorum. Ailemdeki herkes okumuş durumda çocuklarım hep okudu ben kendimi ezik hissediyorum. Plakalara bakarak sayıları öğrendim. Etrafıma bakarak okumayı öğrenmeye çalıştım. Otuz yaşında özürlü çocuğumu bırakıp geliyorum (K18, 52). Dolmuşları okuyamıyorum. Yabancı insanlara her yeri soramıyorum. Çekiniyorum. Okumuşluğun zararı olmaz (K19, 65). Kendimi boşta hissediyorum. Gittiğim yerleri yapacağım işleri bilmiyorum yapamıyorum. Yanlış bir yere imza atmaktan korkuyorum. Oy kullanacağım ama bilmiyorum. Kendimi ezik hissediyorum. Maddi durumumdan sıkıntı yok. Kız kısmı okumaz dediler $(K 20,54)$. Pastaneye yanıma adam almadan gidemiyorum. Tek başıma uzak bir yerden gelemiyorum. Çocuklarım okumamı çok istiyor (K21, 76)."

Yukarıda yer alan görüşler incelendiğinde, görüşme yapılan yetişkinlerin okuma-yazma bilmemeleri nedeniyle günlük yaşamlarında oldukça zorlandıkları görülmektedir. Özellikle K16 (44) tarafından belirtilen "Gelinlere bir şey sormak ağırıma gidiyor." ifadesi çok önemlidir. Yetişkinimiz gelinlere okuma-yazma kapsamında herhangi bir şey sormanın gücüne gittiğini dile getirmiştir.

\section{Tema: Kuran, Kitap, Gazete Okumak Için}

Okuryazar olmayan yetişkinlerin okuma-yazma öğrenme nedenlerinin incelendiği bu araştırmada, verilerin içerik analizi sonucunda ulaşılan ikinci tema, Kuran, kitap, gazete okumak için temasıdır. Bu temada, yetişkinlerin okuma-yazma öğrenme nedenleri arasında Kuran, kitap gazete okuyabilmek amacıyla olduğu belirlenmiş̧ir. Tema ile ilgili olarak görüşme yapılan yetişkinler şunları dile getirmişlerdir:

"Elime gelen geçen kâğıdı okumak istiyorum. Gazete okumak istiyorum (K11, 52). Kuran'ı çatamıyorum $(K 12,55)$. Burada yazan isimleri okuyamıyorum. Kuran'ın Türkçesini okumak istiyorum. Dini kitaplar okumak istiyorum. Kulaktan duyma şeylerden ziyade kendim okumak istiyorum $(K 14,56)$. Okumamı ilerletmek istiyorum. Heceleri çatamıyorum (K15, 57). Kuran okurken harfleri birleştiremiyorum $(K 21,65) . "$

Yukarıda yer alan görüşler incelendiğinde, görüşme yapılan yetişkinlerin okuma-yazma öğrenme nedenlerinin gazete okumak, Kuran okumak, Kuran meali okumak, dini kitaplar okumak olduğu görülmektedir. 


\section{Tema: Hastane Işleri Için}

Okumaz-yazmaz yetişkinlerin okuma-yazma öğrenme nedenlerinin incelendiği bu araştırmada, verilerin içerik analizi sonucunda ulaşılan üçüncü tema, hastane işleri için temasıdır. Bu temada, yetişkinlerin okuma-yazma öğrenme nedenleri arasında hastane işleri amacıyla olduğu belirlenmiştir. Görüşme yapılan yetişkinler, okuma-yazma bilmedikleri için hastane işlerini yürütmede zorluk çektiklerini vurgulamışlardır. Tema ile ilgili olarak görüşme yapılan yetişkinler şunları dile getirmişlerdir:

"Bir yere gidince hiçbir şey bilmiyorum. Yozgat'ta tedavide çok sıkıntı çektim (K8, 49). Kocam üç senedir yatalak. Kocam beni gönderdi. Bende istiyorum ama unutuyorum. Hastam için okuma yazma öğrenmek istiyorum. Etrafımı okuyamıyorum. Hastanede başkaları yardımcı oluyor (K9, 65). Hastanede sırayı takip edemiyorum $(K 13,60)$. Hastanede sıra beklerken ismimi okuyabiliyorum ama diğer şeyleri okuyamıyorum. Bu yüzden üzülüyorum $(K 15,57)$. Hastaneye pastaneye giderken yazıları okuyamıyorum $(K 19,65)$. ilaçlarımı bilmiyorum $(K 20,54) . "$

Yukarıda yer alan görüşler incelendiğinde, görüşme yapılan yetişkinlerin okuma-yazma öğrenme nedenlerinin hastane işlerini yerine getirmek amacıyla olduğu görülmektedir. Yetişkinlerimiz okuma-yazma bilmemeleri sebebiyle, hastane işlerinde başkalarından yardım almaktadırlar. Hastane işlerini yürütürken zorlanmaktadırlar.

\section{Tema: Dolandırılmamak için}

Okuma-yazma bilmeyen yetişkinlerin okuma-yazma öğrenme nedenlerinin incelendiği bu araştırmada, verilerin içerik analizi sonucunda ulaşılan dördüncü ve son tema, dolandırılmamak için temasıdır. Bu temada, yetişkinlerin okuma-yazma öğrenme nedenleri arasında dolandırımamak için okuma-yazma öğrenmek istedikleri belirlenmiştir. Ne yazık ki dolandırıcılar, özellikle yaşlı vatandaşlarımızı dolandırmaya çalışmaktadırlar. Görüşme yapılan yetişkinlerden iki kişi, dolandırıcılara karşı okuma-yazma öğrenmek istediklerini vurgulamışlardır. Tema ile ilgili olarak görüşme yapılan yetişkinler şunları dile getirmişlerdir:

“Geçen sene üç kere beni kandırdılar, dolandırııılar geldi. Polisi arayamadım (K19, 65). Beni dolandırmaya çalıştılar. Beni dolandıramadılar ama komşumu dolandırdılar (K16, 44)."

Yukarıda yer alan görüşler incelendiğinde, görüşme yapılan yetişkinlerin okuma-yazma öğrenme nedenleri arasında dolandırıcılık konusunun yer aldığı anlaşılmaktadır. Bir yetişkinimiz, okuma-yazma bilmediği için polisi arayamadığını vurgulamıştır. 


\section{Tartışma, Sonuç ve Öneriler}

Yetişkinlerin okuma-yazma öğrenme nedenlerinin incelendiği bu araştırmada, dört adet temaya ulaşılmıştır. Araştırma sonucunda ulaşılan, yetişkinlerin okuma-yazma öğrenme nedenleri şunlardır:

1. Gündelik işler için

2. Kuran, kitap, gazete okumak için

3. Hastane işleri için

4. Dolandırılmamak için

Yetişkinlerin okuma yazma öğrenme nedenlerinin incelendiği bu araştırma sonucunda ulaşılan ilk sonuç gündelik işler temasıdır. Yetişkinlerin okuma-yazma öğrenme nedenlerinden ilkinin ve en önemlisinin gündelik işleri amacıyla olduğu tespit edilmiştir. Ulaşılan bu sonuç kapsamında, yetişkinler market alışverişinde, yolculuk sırasında başkalarından yardım almak zorunda olduklarını dile getirmişlerdir. Özellikle bir yetişkin, gelinlerine okuma-yazma konusuyla ilgili bir şey sorduğunda çekindiğini vurgulamıştır. Güneş $(1997$, s. 35) ulaşılan bu sonuca benzer olarak, okuma-yazmanın bireyi başkalarına bağımlı olmaktan kurtarmakta ve kişiyi özgürleştirmekte olduğunu belirtmektedir. Yine araştırma sonucuyla benzer bir şekilde Gülgöz'e (2003, s. 3) göre, okuryazar toplumlarda gündelik yaşamı sürdürmek için gerekli olan birçok işlemi yapmakta okuryazar olmak birincil koşuldur. Bu tür toplumlarda okuryazar olmayan kişiler bir becerinin eksikliğini duymanın yanı sıra toplumda yer almakta ve gündelik işlevleri yerine getirebilmekte sorunlarla karşılaşmaktadırlar. Görüşme yapılan yetişkinler bankamatikten para çekebilmek amacıyla okuma-yazma öğrenmek istediklerini belirtmişlerdir. Araştırma sonucuyla benzer bir şekilde Miser'e (2002, s. 59) göre, günümüzde kişinin yaşam alanında işlevsel olmasına olanak verecek okuma-yazma düzeyi, bilgisayarla vergi formlarını doldurma, otomatik para çekme makinalarını kullanabilme, bilgisayar ve cep telefonuyla posta gönderebilme, elektronik ev aletlerini kullanabilme gibi edimleri yapabilecek düzeydir. Yetişkinlerin okuma-yazma öğrenme nedenlerinin incelendiği bu araştırma sonucunda ulaşılan ikinci sonuç; Kuran, kitap, gazete okumak için yetişkinlerin okuma-yazma kursuna devam etmeleridir. Dini bilgi ve normal bilgi gereksinimi amacıyla okuma-yazma bilmeyen yetişkinlerimizin okuma-yazma kursuna katıldığı görülmektedir. Bilgi edinme isteğinin ne kadar önemli olduğu ortaya çıkmaktadır. Yetişkinlerin okuma-yazma öğrenme nedenlerinin incelendiği bu araştırma sonucunda ulaşılan üçüncü sonuç, hastane işleri için yetişkinlerin okuma-yazma öğrenmek istemeleridir. Görüşme yapılan yetişkinler, okuma-yazma bilmedikleri için hastane işlerini yürütmede zorluk çektiklerini vurgulamışlardır. Hastane işlerini yürütürken başkalarından yardım aldıklarını ve bu durumdan çekindiklerini dile getirmişlerdir. Güneş (1997, s. 35) ulaşılan bu sonuca benzer olarak, okuma-yazmanın bireyi 
diğerlerine bağımlı olmaktan kurtardığını belirtmektedir. Yetişkinlerin okuma-yazma öğrenme nedenlerinin incelendiği bu araştırma sonucunda ulaşılan dördüncü ve son sonuç, dolandırılmamak için yetişkinlerin okuma-yazma öğrenmek istemeleridir. Dolandırıcılar yaşlı insanlarımızı daha kolay kandırabildikleri için sıklıkla bu bireylerimizi dolandırmaya çalışmaktadırlar. Görüşme yapılan yetişkinlerimiz, 155 polis imdat hattını arayabilmek amacıyla okuma-yazma öğrenmek istediklerini dile getirmişlerdir.

Öneriler

Araştırma sonuçları kapsamında şu önerilerde bulunulmuştur:

1. Yetişkinler için okuma-yazma kursları, Milli Eğitim Bakanlığının yanı sıra, belediyeler, vakıflar, dernekler vb. kurumlarca da açılmakta ve desteklenmektedir. Ancak günümüzde okumayazma bilmeyen yetişkinlerimizin olduğu düşünüldüğünde, bu kursların açılma sıklı̆ının artırılması önerilmektedir.

2. Okuma-yazma kurslarına çeşitli nedenlerle gelemeyen yetişkinlerimiz için televizyondan takip edebilecekleri okuma-yazma kurslarının düzenlenmesi önerilmektedir.

3. Okuma-yazma kurslarından sonra kursiyerlerin okuma-yazma gelişimlerinin izlenmesi önerilmektedir. Bu konuda okuma-yazma bilen aile bireyleri tarafından, okuma-yazma kursunu bitiren kişi desteklenmeli ve takip edilmelidir.

\section{Kaynaklar}

Aziz, A. (1981). Yetişkin eğitimi ve okuma yazma seferberliği. Eğitim ve Bilim, 6(31). 8-15.

Beder, H. (1991). Adult literacy: issues for policy and practice. Malabar: Krieger Publishing Co.

Braun, V. ve Clarke V. (2006) Using thematic analysis in psychology. Qualitative Research in Psychology, 3 (2), 77-101.

Durgunoğlu, A. Y., Öney, B., Kuş̧̧ul, H. Ö., ve Cantürk, M. (1997). Işlevsel yetişkin okuryazarlığı programı uygulama ve değerlendirmesi. Anne Çocuk Eğitim Vakfı.

Fingeret, H. A. ve Drennon, C. (1997). Literacy for life: adult learners, new practices. New York: Teachers College Press.

Gülgöz, S. (2003). Işslevsel yetişkin okuryazarlığı programı değerlendirme araştırması. Anne Çocuk Eğitim Vakfı.

Güneş, F. (1991). Yetişkinlerin okuma-yazmayı unutma nedenleri. Ankara Üniversitesi Eğitim Bilimleri Fakültesi Dergisi, 1 (24), 21-36.

Güneș, F. (1997). Okuma-yazma öğretimi ve beyin teknolojisi. Ankara: Ocak Yayınları.

Mace, J. (1992). Talking about literacy: principles and practice of adult literacy education. London: Routledge.

MEB (Millî Eğitim Bakanlığı Hayat Boyu Öğrenme Genel Müdürlüğü) (2018). Yetişkinler I. kademe okuma yazma öğretimi ve temel eğitim programı. Ankara.

Merriam, S. B. (2013). Nitel araştırma desen ve uygulama için bir rehber. Selahattin Turan (Çeviri Editörü). Ankara: Nobel Akademik Yayıncılık. 
Mezirow, J. (1996). Toward a learning theory of adult literacy. Adult Basic Education, 6(3), 115-126.

Miles, B. ve Huberman, M. (2015). Genişletilmiş bir kaynak kitap: nitel veri analizi (Çev. Ed: Sadegül Akbaba Altun - Ali Ersoy). Ankara: Pegem Akademi.

Miser, R. (2002). Küreselleşen dünyada yetişkin eğitimi. Ankara Üniversitesi Eğitim Bilimleri Fakültesi Dergisi, 35 (1), 55-60.

Patton, M. Q. (2014). Nitel araştırma ve değerlendirme yöntemleri (3. Baskıdan Çeviri). (Çeviri Editörleri: Mesut Bütün, Selçuk Beşir Demir). Ankara: Pegem Akademi.

Quigley, B. A. (1997). Rethinking literacy education. The critical need for practice-based change. The jossey-bass higher and adult education series. San Francisco: Jossey-Bass Publishers, Inc.

Rogers, A. (1992). Adults learning for development. New York: Cassell Educational Limited.

Yıldırım, A. ve Şimşek, H. (2006). Sosyal bilimlerde nitel araştırma yöntemleri (6. baskı). Ankara: Seçkin Yayıncılık.

\section{Extended Abstract}

Introduction

Adult education is meticulously addressed in our country like in other countries in the world. Various courses are offered by the Ministry of National Education in municipalities and in penitentiaries for adults. One of these courses is literacy courses for adults. Literacy courses for adults involve learning to read and write in an accelerated manner in a short period of time. Adults who were not able to go to elementary school for various reasons or who could not learn to read and write is taught to read and write without any cost. When adult literacy courses are examined, it is seen that a large majority of the participants are women. At the beginning of the study, adult education was first explained. Then, the importance of literacy learning for adults was emphasized. Later, the literacy campaign of 2018 in Turkey was touched upon. Finally, the literacy curriculum for adults was discussed. The purpose of this research was to determine the reasons why adults who attended literacy courses began these courses. Research is important in order to explain why some adults in Turkey have not learned to read and write, to express the consequences of illiteracy, and to explain the reasons for adults to learn to read and write.

\section{Method}

The study was designed using a qualitative research method, namely, phenomenology. In phenomenology research, we focus on phenomena which we are aware of, yet we do not have an in-depth and detailed understanding of them. Phenomenology is an appropriate research method for issues that are not entirely foreign to us; we also intend to investigate those phenomena we cannot fully grasp. Easy access case sampling was used in the purposeful sampling of the participants. Twenty-one adult participants, attending the literacy course in the Yozgat province were reached. A semi-structured interview form developed by the researchers was used as the data collection tool. In order to draft the semi-structured interview form, the related literature was reviewed first. Interview questions were developed afterwards. The semi-structured interview form was presented to an expert lecturer in the field of teaching Turkish and an expert in the field of qualitative research methods. After obtaining expert opinions, the questions in the semi-structured interview form were abridged and simplified. The research was conducted in March 2018. Within the scope of the study, twenty-one adults who participated in the literacy course were interviewed. The interview calls were recorded on the voice recorder after the permission was received. Informal interviews also continued during breaks in the reading and writing course. A total recording time of 256 minutes was made. In the analysis of the data, inductive analysis was used for thematic analysis. In the thematic analysis of the data, coding was done by the researchers and by a lecturer who specialized in qualitative research methods.

\section{Result and Discussion}

In this study, in which adult literacy learning reasons were examined, four themes emerged as the result of the thematic analysis of the data. The results showed that the reasons adults were learning literacy could be summed up under four themes: daily work, reading the Quran and other printed materials, seeking medical care in hospitals, and avoiding defraudation. In this study, in which adult literacy learning reasons were examined, it was determined that the first and the most important reason for adults to learn to read and write were to use literacy for their daily tasks. The participating adults stated that they had to get help from others for ordinary daily tasks such as shopping at the marketplace. In particular, an adult emphasized that he had to ask for help from his brides when he needed to read or write something. 
The second reason that emerged as the result of the thematic analysis of the data was to read the Qur'an, books, and newspapers. The third reason was seeking medical care in hospitals. In this case, it was determined that adults were learning to read and write for hospital work. The interviewed adults emphasized that they had difficulty in hospitals because they did not know how to read and write. The fourth and final reason was to avoid defraudation. Unfortunately, fraudsters try to defraud the elderly. Two of the interviewed adults emphasized that they wanted to learn to read and write to protect themselves from fraudsters.

Based on the findings in this study, the following suggestions were made:

1. The number and frequency of adult literacy courses should be increased.

2. Courses should be set up for adults who cannot come to literacy courses for various reasons.

3. After literacy courses end, developments made by the participants should be monitored. In this respect, a person who finishes the literacy course should continue to be supported and monitored by literate family members. 